\title{
Knowledge Management, the Effects of Job Stress, Job Satisfaction, Organizational Commitment, and Workplace Bullying to Turnover Intention
}

\author{
Riska Sari Dewi, Zainul Bahri Dalimunthe, B. Medina Nilasari* \\ Magister Management \\ Universitas Trisakti \\ Jakarta, Indonesia \\ *medina@trisakti.ac.id
}

\begin{abstract}
This research was to investigate the effects of job stress, job satisfaction, organizational commitment and workplace bullying to turnover intention. The problem of this research was turnover intention in managing human resources where the intensity of employee turnover is increasing. In the suspected cause of the problem occurs in the variable job stress, job satisfaction, organizational commitment, and workplace bullying. The object was PT Prudential's sales agent employees. This study was conducted by distributing questionnaires to 107 people and a 102 return questionnaire with a $90 \%$ response rate. The data analysis was Regression Analysis. However, before the method is applied there is validity test, reliability test, and classic assumed test first. The findings as follows: (1) There is influence significant between variable job stress to turnover intention; (2) There is influence significant between variable job satisfaction to turnover intention; (3) There is influence significant between variable organizational commitment to turnover intention; (4) There is influence significant between variable workplace bullying to turnover intention; (5) There is influence significant between variable job stress, job satisfaction, organizational commitment, workplace bullying both in simultaneous to turnover intention. The results of this study prove that the influence of organizational commitment, job stress, job satisfaction, and bullying at work should be paid more attention to reduce employee turnover intention.
\end{abstract}

Keywords-job stress, job satisfaction, organizational commitment, workplace bullying, and turnover intention

\section{INTRODUCTION}

All processes of the company's operating activities cannot run well without the support of adequate and quality human resources, so that the accuracy in organizing all activities can achieve optimal results. The inability to manage human resources will have a direct or indirect impact on the organization. One form of employee management inability has an impact on the behaviour of employees who tend to move and lead to the employee's decision to leave their job [1]. The problem that occurs today in PT. Prudential which is one of the many companies engaged in insurance services that is very competitive in the country, is that there is a high turnover that will decrease the company's performance to achieve the desired goals effectively and efficiently. Turnover that continues to increase will have an impact on the intention to change jobs to other employees in the company. To determine whether there is turnover intention, the researcher first distributes an initial questionnaire to several employees with 3 questions to find out how much the employee wants to move (turnover intention) from the company. The following results from the initial questionnaire are shown in Table 1 below:

TABLE I. INITIAL SURVEY RESUlt DATA OF TURNOVER INTENTION

\begin{tabular}{|l|l|l|cr|cc|}
\hline No. & $\begin{array}{c}\text { Length } \\
\text { of work }\end{array}$ & $\begin{array}{c}\text { How long } \\
\text { have you } \\
\text { worked in } \\
\text { this } \\
\text { company? }\end{array}$ & \multicolumn{2}{|c|}{$\begin{array}{c}\text { Do you feel } \\
\text { happy } \\
\text { working in } \\
\text { this } \\
\text { company? }\end{array}$} & \multicolumn{2}{|c|}{$\begin{array}{c}\text { Have you ever } \\
\text { intended to } \\
\text { leave the } \\
\text { company? }\end{array}$} \\
\hline & & & YES & NO & YES & NO \\
\hline 1. & $<1$ thn & 22 & 14 & 21 & 25 & 2 \\
\hline 2. & $1-4$ thn & 21 & 6 & 2 & 14 & 3 \\
\hline 3. & $>4$ thn & 14 & 10 & 4 & 2 & 11 \\
\hline \hline & Total : & $\mathbf{5 7}$ & $\mathbf{3 0}$ & $\mathbf{2 7}$ & $\mathbf{4 1}$ & $\mathbf{1 6}$ \\
\hline
\end{tabular}

Source: Preliminary Results Survey at PT. Prudential (2017).

From Table 1, it can be seen that the level of turnover intention is quite high. If a turnover occurs, it means the company loses a number of workers. This loss must be replaced with new employees, thus the company must pay for new workers. In addition, turnover intention tends to have a negative impact on the company because it creates instability in labour conditions, reduces employee productivity, creates a work atmosphere that is not conducive, and has an impact on increasing human resource costs. Based on the results of previous research there are many factors that cause turnover intention in employees, namely job stress, job satisfaction [2], organizational commitment [3] and workplace bullying [4]. The novelty of this study is to simultaneously examine the influence of job stress factors, job satisfaction, organizational commitment, and workplace bullying on turnover intention. 
Job stress has become a common problem for human resources today and is the concern of all stakeholders and employees in the company, various researchers have concluded that stress at work is a problematic issue for various organizations [5]. Job satisfaction can affect someone thinking of leaving the organization. Evaluation of various job alternatives will eventually result in turnover because individuals choose to leave the organization in the hope of getting more satisfying results elsewhere [6]. Employee commitment to the organization is one of the important keys in determining the success or failure of an organization to achieve its goals. Organizational commitment has a meaning that is more than just passive loyalty, but also involves active relationships and the desire of employees to make meaningful contributions to their organization [7]. If an employee has a high level of commitment to the organization, whether it is fun or not, the employee will remain with the organization in a state of joy or sorrow. Another suspected factor was workplace bullying. Many researchers have reported that being the target of bullying will produce psychological problems such as fear, anxiety, helplessness, depression and post-traumatic stress disorder [8]. At the organizational level, it negatively affects employee commitment, job satisfaction, absenteeism, and staff turnover rates [4]. Based on the description above, this study aims to examine the effect of job stress, job satisfaction, organizational commitment, and workplace bullying on turnover intention.

Therefore, a knowledge management is needed in an organization so that it is well managed. In the context of implementing knowledge management, human resources (people) are not systems, but organizations can empower human resources to share and manage knowledge and the success of knowledge management can increase organizational productivity in various fields $[9,10]$.

\section{THEORETICAL REVIEW}

\section{A. Job Stress}

Stress is connected to certain psychological issues, for example problems such as anxiety, low self-esteem and motivation, mood variations. This consequence will reduce performance, job satisfaction and increase turnover intention without considering gender [11]. Job stress is a relatively diverse phenomenon of contemporary lifestyle [5]. Another opinion expressed by Greenberg and Baron [12], stress is a pattern of emotions and physiological reactions that occur in response to demands from within or outside the organization. It can be concluded that work is a condition that makes a person stressed because of the many demands, pressures and excessive workload that are beyond one's ability at work, which will affect their performance.

\section{B. Job Satisfaction}

Robbins and Judge [13] define job satisfaction as a positive feeling about work as a result of evaluating its characteristics. Job satisfaction is closely related to the process of withdrawal cognition, the intention to leave and the real action in the form of turnover [14]. It can be explained that job satisfaction refers to the expression of feelings and attitudes of employees towards their work, that the jobs that have been done so far have the results expected by employees, making employees feel satisfied to be able to minimize employee turnover in the company.

\section{Organizational Commitment}

Organizational commitment has 3 dimensions as follows [3]: (1) Affective Commitment is the emotional attachment and involvement of employees to the organization. (2) Commitment Continuance is a commitment based on perceptions of losses associated with leaving the employee (resigning) from the organization. (3) Normative Commitment is a commitment based on the involvement of employees' feelings about the obligation to remain in the organization for moral or ethical reasons. Employees worry that they will be label bad if they leave the organization.

\section{Workplace Bullying}

Workplace bullying is a situation where a person is repeatedly and during a period of time exposed to negative actions from colleagues, superiors or subordinates [15]. Workplace bullying includes situations where the person feels abused at work for a long time in such a way that he doesn't have the opportunity to defend himself [4]. Experiencing a series of bullying behaviour that cause him to feel intimidated or harassed, this means that bullying is present. Furthermore workplace bullying ranges from the most subtle, even unconscious, to the most overt, deliberate, emotional abuse that includes negative behaviour [16]. Based on some of the views of the experts above, it can be concluded that workplace bullying is a situation where a person experiences negative actions such as persecution, harassment and social exclusion at work which will lower one's self-esteem so that it will cause stress, depression, fear and anxiety.

Schematically this conceptual framework is depicted in the research paradigm as shown in Figure 1.

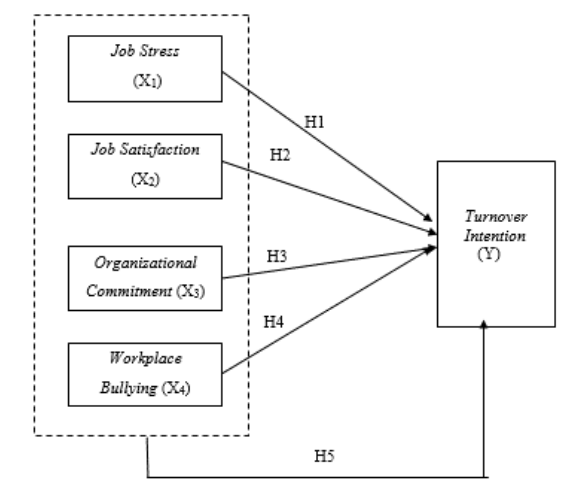

Fig. 1. Conceptual framework 


\section{E. Hypothesis}

The effects of stress associated with behaviour include changes in productivity, high employee turnover, high absenteeism levels and work accidents [13]. A significant relationship between stress levels and employee desires to quit and high levels of stress also affected the high employee turnover rate found by Noor and Maad [17]. From the above opinion, the first hypothesis can be proposed as follows:

H1: Job stress has a significant effect on turnover intention.

The impact of job satisfaction on employee performance includes several things including productivity, absence, and resignation [13]. Companies can expect that if job satisfaction increases, employee turnover and attendance will decrease or vice versa [1]. From the above opinion, the second hypothesis can be proposed as follows:

H2: Job satisfaction has a significant effect on turnover intention.

Organizational commitment is seen as an individual psychological relationship with the organization and is characterized by a strong identification with the organization and a desire to contribute to the fulfilment of organizational goals [3]. If the commitment of employees with the organization is high and employees are fully engaged in achieving goals, they will be motivated and reduce the intention to move from work. From the above opinion, a third hypothesis can be proposed as follows:

H3: Organizational commitment has a significant effect on turnover intention.

At the individual level, produce psychological problems such as fear, anxiety, helplessness, depression and posttraumatic stress disorder [8]. At the organizational level, it negatively affects employee commitment, job satisfaction, absenteeism and turnover intention [4]. From the above opinion, the fourth and fifth hypotheses can be proposed as follows:

H4: Workplace bullying has a significant effect on turnover intention.

H5: Job stress, job satisfaction, organizational commitment, workplace bullying simultaneously have a significant effect on turnover intention.

\section{METHODS}

\section{A. Variables and Measurements}

The variables in the study can be divided into: (1) The independent variables in this study are job stress (X1), job satisfaction (X2), organizational commitment (X3), workplace bullying (X4). (2). The dependent variable in this study is turnover intention. For more details, the variables and measurements used in this study are presented as follows: (1) the job stress variable as an independent variable has dimensions and indicators, namely the first dimension is role ambiguity with task indicators, the second dimension feedback role conflict has inter sender, personal indicators. -role, and the third dimension of role overload with qualitative, quantitative indicators. The following is a breakdown of the job stress variable questions [18] (See Table 2):

TABLE II. LIST OF Job STRESS VARIABLE QUESTIONS

\begin{tabular}{|l|l|}
\hline No & \multicolumn{1}{|c|}{ Statements } \\
\hline 1 & $\begin{array}{l}\text { I don't understand clearly if I am faced with a new work } \\
\text { situation. }\end{array}$ \\
\hline 2 & My boss didn't give me clear enough instructions. \\
\hline 3 & $\begin{array}{l}\text { I feel the feedback that the company gave me did not match my } \\
\text { expectations. }\end{array}$ \\
\hline 4 & $\begin{array}{l}\text { My role in the company has recently been reduced so I feel that } \\
\text { I have become less important in the company. }\end{array}$ \\
\hline 5 & I have to do work that goes against my opinion. \\
\hline 6 & Current work demands a great speed in completion. \\
\hline 7 & $\begin{array}{l}\text { The company gives you the freedom to complete tasks with } \\
\text { your own method }\end{array}$ \\
\hline 8 & I feel that my current job does not match the abilities I have. \\
\hline 9 & My current job requires me to have high skills \\
\hline 10 & Tricky tasks demands \\
\hline 11 & The company demands that I get my work done immediately \\
\hline 12 & I have an excessive workload \\
\hline
\end{tabular}

The job satisfaction variable as an independent variable has the following dimensions and indicators, namely the first dimension, work itself with indicators of interesting assignments, learning opportunities. The second dimension is present pay with indicators of suitability for work, conformity with employee expectations. Furthermore, the third dimension of promotion has an indicator of opportunities to develop themselves, broaden work experience, opportunities for promotion and other promotions. The fourth dimension is supervision, the indicator is the ability to provide commands and instructions, and pleasant or unpleasant feelings felt by employees. The fifth dimension of co-workers has indicators, namely a comfortable working atmosphere, moral support, assistance at work. The following is a breakdown of the job satisfaction variable questions [19] (See Table 3):

TABLE III. LIST OF JOB SATISFACTION VARIABLE QUESTIONS

\begin{tabular}{|l|l|}
\hline No & \multicolumn{1}{|c|}{ Statements } \\
\hline 1 & My current type of work matches my educational background. \\
\hline 2 & I love my job. \\
\hline 3 & I can develop my potential in this company. \\
\hline 4 & I prefer to do other work. \\
\hline 5 & My salary is adequate, with the responsibility that I bear. \\
\hline 6 & Companies provide better salaries than competitors. \\
\hline 7 & The salary I receive can cover my future needs. \\
\hline 8 & I received quite a lot of allowances. \\
\hline 9 & I am proud of my colleagues' willingness to criticize me. \\
\hline 10 & If I do my job well, I will be promoted \\
\hline 11 & I am satisfied with my progress at work. \\
\hline 12 & Sometimes I feel dissatisfied with the work I do. \\
\hline 13 & Promotion rarely occurs in my company. \\
\hline 14 & $\begin{array}{l}\text { The company imposes promotion criteria for all employees } \\
\text { without favoritism. }\end{array}$ \\
\hline
\end{tabular}


TABLE III. Cont.

\begin{tabular}{|l|l|}
\hline No & \multicolumn{1}{c|}{ Statements } \\
\hline 15 & My boss gives directions well on the job. \\
\hline 16 & My boss appreciates my work. \\
\hline 17 & My boss treats employees fairly. \\
\hline 18 & I feel work friends are friends to share feelings. \\
\hline 19 & Office friends congratulate me when I am achieving success. \\
\hline 20 & $\begin{array}{l}\text { I am happy that my colleagues at work can help each other in } \\
\text { my work. }\end{array}$ \\
\hline
\end{tabular}

The organizational commitment variable as an independent variable has the following dimensions and indicators, namely affective commitment (emotional attachment to the organization, employee involvement in the organization), then the second dimension and indicator, namely continuance commitment (loss irrelevance, loss of position, irrelevance of family relations with colleagues) and the last dimension and indicator of organizational commitment, namely normative commitment (attachment to the obligation to remain in the organization, and the need to stay due to pressure from others worried about being label badly by colleagues). Here are the details of the variable organizational commitment questions [3] (See Table 4):

TABLE IV. LIST OF ORGANIZATIONAL COMMITMENT VARIABLES

\begin{tabular}{|l|l|}
\hline No & \multicolumn{1}{c|}{ Statements } \\
\hline 1 & I pride myself on this company to others outside the company. \\
\hline 2 & I feel part of the family at this company. \\
\hline 3 & $\begin{array}{l}\text { I don't think I will be as easily attached to another company as I } \\
\text { am with this company. }\end{array}$ \\
\hline 4 & I really felt as if the company's problems were my own. \\
\hline 5 & It would cost me too much to leave this company. \\
\hline 6 & $\begin{array}{l}\text { One of the main reasons, I continue to work at this company is } \\
\text { that leaving the company will require a huge sacrifice because of } \\
\text { the overall benefits I get here. }\end{array}$ \\
\hline 7 & $\begin{array}{l}\text { I am worried about what might happen if I quit my job without } \\
\text { having another similar job. }\end{array}$ \\
\hline 8 & Currently working in this company is both my need and my wish. \\
\hline 9 & $\begin{array}{l}\text { Many things in my life will be disturbed if I decide to leave this } \\
\text { company now. }\end{array}$ \\
\hline 10 & I feel that I have few options if I want to leave this company. \\
\hline
\end{tabular}

Workplace bullying variable as an independent variable has the following indicators: (a) Pressure from other people to do work below the level of competence. (b) Insulted or given offensive comments about you. (c) Being treated in a disrespectful and rude manner. (d) Being humiliated or ridiculed in connection with your work. Here are the details of the variable workplace bullying questions [16] (See Table 5):

TABLE V. LIST OF BULLYING WORKPLACE VARIABLE QUESTIONS

\begin{tabular}{|l|l|}
\hline No & \multicolumn{1}{|c|}{ Statements } \\
\hline 1 & I am under pressure to complete work I am not good at. \\
\hline 2 & I am sometimes insulted/given hurtful comments at the company. \\
\hline 3 & I felt treated disrespectfully in the company. \\
\hline 4 & $\begin{array}{l}\text { If I make mistakes in my work then I am often humiliated and } \\
\text { ridiculed. }\end{array}$ \\
\hline 5 & I have experienced physical violence at work. \\
\hline
\end{tabular}

Turnover intention as the dependent variable has the following dimensions and indicators: the first dimension is thought of leaving with an indicator of thoughts of leaving. Furthermore, the second dimension is looking for new jobs with an indicator of the desire to find other job vacancies. The last dimension is accepting chances with indicators of evaluating the possibility of finding a decent job elsewhere, and the desire to leave the organization. Here are the details of the variable turnover Intention questions [19] (See Table 6):

TABLE VI. TURNOVER INTENTION VARIABLE QUESTIONNAIRE

\begin{tabular}{|l|l|}
\hline No & \multicolumn{1}{|c|}{ Statements } \\
\hline 1 & $\begin{array}{l}\text { I often experience conflicts in carrying out my assigned duties so } \\
\text { that I have thoughts of leaving this company. }\end{array}$ \\
\hline 2 & $\begin{array}{l}\text { I thought that I would not work in this company for another three } \\
\text { years. }\end{array}$ \\
\hline 3 & I want to find a job other than my current profession. \\
\hline 4 & I often look for other job vacancies. \\
\hline 5 & I will look for a better job, according to my education level. \\
\hline 6 & $\begin{array}{l}\text { I want to find another job because the salary is not what I } \\
\text { expected }\end{array}$ \\
\hline 7 & $\begin{array}{l}\text { After I get a better job, I will immediately move from this } \\
\text { company. }\end{array}$ \\
\hline 8 & I want to leave this job in the near future. \\
\hline
\end{tabular}

The variables and indicators in this study were measured using a Likert scale with 4 levels of answers as follows: Strongly Agree with a score of 4; Agree with a score of 3; Disagree with a score of 2; Strongly Disagree with a score of 1 .

\section{B. Samples}

Sales Agent employees of PT. Prudential located on K.H. Mas Mansyur Kav. 126 Central Jakarta. That will be the target of the research sample. The total population used was 147 people, with the calculation of the Slovin formula, the number of samples was 107 people. The questionnaire data returned were 102 with a response rate of $90 \%$. The sampling technique in this study is the probability sampling technique, which is a sampling technique that provides equal opportunities for each member of the population.

\section{Data Analysis}

The data analysis method used is simple regression analysis and multiple regression. Then analysis of the determinant coefficient (R2) is carried out to determine how much the percentage contribution of the influence of the independent variables simultaneously to the dependent variable. To determine whether there is an effect of independent variables on the dependent variable, hypothesis testing is carried out as follows: (a) $\mathrm{F}$ test (simultaneous significance testing). The $\mathrm{F}$ test is basically used to test the significance of the effect of several independent variables on the dependent variable. (b) $t$ test (partial significance test): $t$ test is used to test the significance of the relationship between variable $X$ and variable $\mathrm{Y}$, whether the variables $\mathrm{X} 1, \mathrm{X} 2$ really affect variable Y. 


\section{RESULTS AND DISCUSSION}

TABLE VII. Summary Model Job Stress (X1) TO TURNOVER INTENTION (Y)

\begin{tabular}{|c|c|c|c|c|}
\hline \multicolumn{5}{|c|}{ Model Summary } \\
\hline Model & $\mathbf{R}$ & $\begin{array}{c}\mathbf{R} \\
\text { Square }\end{array}$ & $\begin{array}{l}\text { Adjusted R } \\
\text { Square }\end{array}$ & $\begin{array}{c}\text { Std. error of the } \\
\text { Estimate }\end{array}$ \\
\hline 1 & $.494^{\mathrm{a}}$ & .244 & .236 & .58899 \\
\hline
\end{tabular}

Source: Data Processing 2018

Based on Table 7, to answer the problem "is there a relationship between job stress variables and turnover intention", which is 0.494 (See R in the Model Summary table). The relationship between the independent variable and the dependent variable has a strong enough relationship (in the range $0.40-0.599)$. To answer the problem "does the frequency of job stress affect turnover intention". In this case using R Square or also called the coefficient of determination (KD). The coefficient of determination is 0.244 or equal to $24.4 \%$. This means that the effect of job stress on turnover intention is $24.4 \%$ and the remaining $75.6 \%(100 \%-24.4 \%)$ is influenced by other variables that are not explained in this study. The possibility of unexplained variables such as burnout, as well as working conditions in the company such as internal factors that can cause stress in a person are determined by personality, abilities and cultural values [20].

TABLE VIII. ANOVA JoB STRESS (X1) TO TURNOVER INTENTION (Y)

\begin{tabular}{|c|l|l|l|l|l|c|}
\hline \multicolumn{1}{|c|}{ Model } & $\begin{array}{c}\text { Sum of } \\
\text { Squares }\end{array}$ & \multicolumn{1}{|c|}{ df } & $\begin{array}{c}\text { Mean } \\
\text { Square }\end{array}$ & F & Sig. \\
\hline 1 & Regression & 11.194 & 1 & 11.194 & 32.268 & $.000^{\mathrm{a}}$ \\
& Residual & 34.691 & 100 & .347 & & \\
& Total & 45.885 & 101 & & & \\
\hline
\end{tabular}

a. Predictors: (Constant), Job Stress (JS) X1

b. Dependent Variable: Turnover Intention (TI) Y

Source: Data Processing 2018.

Based on Table 8 , has a probability value of Sig. $=0.000$ $<0.05$, then Ho is rejected and Ha is accepted. It means that the regression coefficient is significant. The conclusion is that job stress has a significant effect on turnover intention.

TABLE IX. COEFFICIENTS JoB STRESS (X1) TO TURNOVER INTENTION (Y)

\begin{tabular}{|c|c|c|c|c|c|c|}
\hline \multicolumn{7}{|c|}{ Coefficients $^{\mathbf{a}}$} \\
\hline \multirow{2}{*}{\multicolumn{2}{|c|}{ Model }} & \multicolumn{2}{|c|}{$\begin{array}{l}\text { Unstandardized } \\
\text { Coefficients }\end{array}$} & \multirow{2}{*}{$\begin{array}{c}\begin{array}{c}\text { Standardized } \\
\text { Coefficients }\end{array} \\
\text { Beta }\end{array}$} & \multirow[t]{2}{*}{$\mathbf{t}$} & \multirow[t]{2}{*}{ Sig. } \\
\hline & & B & $\begin{array}{c}\text { Std. } \\
\text { Error }\end{array}$ & & & \\
\hline 1 & $\begin{array}{l}\text { (Constant) } \\
\text { Job Stress (JS) X1 }\end{array}$ & $\begin{array}{l}1.010 \\
.575\end{array}$ & $\begin{array}{l}.307 \\
.101\end{array}$ & .494 & $\begin{array}{l}3.289 \\
5.681\end{array}$ & $\begin{array}{l}.001 \\
.000\end{array}$ \\
\hline
\end{tabular}

Source: Data Processing 2018
Based on Table 9, a constant number of 1,010 states that if there is job stress, turnover intention is reduced by 1,010 . The regression coefficient for the $\mathrm{X} 1$ variable is 0.575 which means that for each increase in the value of job stress (X1) it causes an increase in turnover intention (Y) by 0.575 units. Contains a positive meaning, indicating a unidirectional relationship between job stress (X1) and turnover intention (Y). So the higher the job stress, the higher the turnover intention, and vice versa if the decrease in job stress, the lower the turnover intention for employees. TABLE X. SUMmary MODEL Job SATISFACTION (X2) TO TURNOVER
INTENTION (Y)

\begin{tabular}{|l|c|c|c|c|}
\hline Model & R & $\begin{array}{c}\text { R } \\
\text { Square }\end{array}$ & $\begin{array}{c}\text { Adjusted R } \\
\text { Square }\end{array}$ & $\begin{array}{c}\text { Std. error of the } \\
\text { Estimate }\end{array}$ \\
\hline 1 & & .191 & .183 & .60939 \\
\hline \multicolumn{5}{|c}{ a. Predictors: (Constant), Job Satisfaction (JSF) X2. } \\
\hline \multicolumn{4}{|c|}{ Source: Data Processing 2018.}
\end{tabular}

Based on Table 10, to answer the problem "is there a relationship between job stress variables and turnover intention", which is 0.437 (See R in the Model Summary table). The relationship between the independent variable and the dependent variable has a strong enough relationship (in the range 0.40 - 0.599). To answer the problem "whether job satisfaction frequency affects turnover intention". In this case using R Square or also called the coefficient of determination (KD). The coefficient of determination is 0.191 or equal to $19.1 \%$. This means that the influence of job stress on turnover intention is $19.1 \%$ and the remaining $80.9 \%(100 \%-19.1 \%)$ is influenced by other variables that are not explained in this study. Possible unexplained variables such as motivation, individual factors related to people's attitudes towards work, employee performance appraisals, career planning, job insecurity, compensation, or job training.

TABLE XI. ANOVA Job SATISFACTION (X2) TO TURNOVER INTENTION (Y)

\begin{tabular}{|c|c|c|c|c|c|c|}
\hline \multicolumn{7}{|c|}{ ANOVA $^{b}$} \\
\hline & Model & $\begin{array}{c}\text { Sum of } \\
\text { Squares }\end{array}$ & df & $\begin{array}{c}\text { Mean } \\
\text { Square }\end{array}$ & $\mathbf{F}$ & Sig. \\
\hline 1 & $\begin{array}{l}\text { Regression } \\
\text { Residual } \\
\text { Total }\end{array}$ & $\begin{array}{l}8.750 \\
37.135 \\
45.885\end{array}$ & $\begin{array}{l}1 \\
100 \\
101\end{array}$ & $\begin{array}{l}8.750 \\
.371\end{array}$ & 23.563 & $.000^{\mathrm{a}}$ \\
\hline
\end{tabular}

Source: Data Processing 2018

Based on Table 11, has a probability value of Sig. $=0.000$ $<0.05$, then Ho is rejected and $\mathrm{Ha}$ is accepted. It means that the regression coefficient is significant. The conclusion is that job satisfaction has a significant effect on turnover intention. 
TABLE XII. COEFFICIENTS JOB SATISFACTION (X2) TO TURNOVER INTENTION (Y)

\begin{tabular}{|c|c|c|c|c|c|c|}
\hline \multicolumn{7}{|c|}{ Coefficients $^{\mathrm{a}}$} \\
\hline \multirow{2}{*}{\multicolumn{2}{|c|}{ Model }} & \multicolumn{2}{|c|}{$\begin{array}{c}\text { Unstandardized } \\
\text { Coefficients }\end{array}$} & \multirow{2}{*}{$\begin{array}{c}\begin{array}{c}\text { Standardized } \\
\text { Coefficients }\end{array} \\
\text { Beta }\end{array}$} & \multirow[t]{2}{*}{$\mathbf{t}$} & \multirow[t]{2}{*}{ Sig. } \\
\hline & & B & $\begin{array}{c}\text { Std. } \\
\text { Error }\end{array}$ & & & \\
\hline 1 & (Constant) & 3.810 & .232 & & 16.421 & .000 \\
\hline & $\begin{array}{l}\text { Job Satisfaction } \\
\text { (JSF) } \mathrm{X} 2\end{array}$ & .497 & .102 & .437 & -4.854 & .000 \\
\hline
\end{tabular}

a. Dependent Variable: Turnover Intention (TI) Y

Source: Data Processing 2018

Based on Table 12, a constant figure of 3,810 states that if there is job satisfaction, turnover intention is reduced by 3,810 . The regression coefficient for the $\mathrm{X} 2$ variable is - 0.497 , which means that it is negative, indicating that there is an opposite relationship between job satisfaction (X2) and turnover intention. For each increase in the value between job satisfaction (X2), the rate of turnover intention (Y) decreases by 0.497 units. So the higher the job satisfaction, the lower the turnover intention, and vice versa if the decrease in job satisfaction, the turnover intention will also increase the employee's level.

TABLE XIII. SUMmary MODEL ORGANIZATIONAL COMMITMENT (X3) TO TURNOVER INTENTION (Y)

\begin{tabular}{|l|c|c|c|c|}
\hline Model & $\mathbf{R}$ & $\begin{array}{c}\text { R } \\
\text { Square }\end{array}$ & $\begin{array}{c}\text { Adjusted R } \\
\text { Square }\end{array}$ & $\begin{array}{c}\text { Std. error of the } \\
\text { Estimate }\end{array}$ \\
\hline 1 & $.592^{\mathrm{a}}$ & .351 & .344 & .54580 \\
\hline \multicolumn{5}{|c}{ a. Predictors: (Constant), Organizational Commitment (OC) X }
\end{tabular}

Source: Data Processing 2018

Based on Table 13, to answer the problem "is there a relationship between organizational commitment variables to turnover intention", which is 0.592 (See R in the Model Summary table). The relationship between the independent variable and the dependent variable has a strong enough relationship (in the range 0.40 - 0.599). To answer the problem "whether the frequency of organizational commitment affects turnover intention". In this case using R Square or also called the coefficient of determination (KD). The coefficient of determination is 0.351 or equal to $35.1 \%$. This means that the influence of organizational commitment on turnover intention is $35.1 \%$ and the remaining $64.9 \%(100 \%-35.1 \%)$ is influenced by other variables that are not explained in this study. One example is organizational culture, and career advancement.
TABLE XIV. ANOVA ORGANIZATIONAL COMMITMENT (X3) TO TURNOVER INTENTION (Y)

\begin{tabular}{|c|c|c|c|c|c|c|}
\hline \multicolumn{7}{|c|}{ ANOVA $^{b}$} \\
\hline & Model & $\begin{array}{c}\text { Sum of } \\
\text { Squares }\end{array}$ & df & $\begin{array}{c}\text { Mean } \\
\text { Square }\end{array}$ & $\mathbf{F}$ & Sig. \\
\hline 1 & $\begin{array}{l}\text { Regression } \\
\text { Residual } \\
\text { Total }\end{array}$ & $\begin{array}{l}16.095 \\
29.790 \\
45.885\end{array}$ & $\begin{array}{l}1 \\
100 \\
101\end{array}$ & $\begin{array}{l}16.095 \\
.298\end{array}$ & 54.028 & $.000^{\mathrm{a}}$ \\
\hline
\end{tabular}

a. Predictors: (Constant), Organizational Commitment (OC) X3

b. Dependent Variable: Turnover Intention (TI) Y Source: Data Processing 2018

Based on Table 14, has a probability value of Sig. $=0.000$ $<0.05$, then Ho is rejected and $\mathrm{Ha}$ is accepted. It means that the regression coefficient is significant. The conclusion is that organizational commitment has a significant effect on turnover intention.

TABLE XV. ORGANIZATIONAL COMMITMENT (X3) COEFFICIENTS TO TURNOVER INTENTION $(\mathrm{Y})$

\begin{tabular}{|c|c|c|c|c|c|c|}
\hline \multicolumn{7}{|c|}{ Coefficients $^{\mathbf{a}}$} \\
\hline \multirow{2}{*}{\multicolumn{2}{|c|}{ Model }} & \multicolumn{2}{|c|}{$\begin{array}{l}\text { Unstandardized } \\
\text { Coefficients }\end{array}$} & \multirow{2}{*}{$\begin{array}{c}\begin{array}{c}\text { Standardized } \\
\text { Coefficients }\end{array} \\
\text { Beta }\end{array}$} & \multirow[t]{2}{*}{$\mathbf{t}$} & \multirow[t]{2}{*}{ Sig. } \\
\hline & & $\mathbf{B}$ & $\begin{array}{l}\text { Std. } \\
\text { Error }\end{array}$ & & & \\
\hline 1 & $\begin{array}{l}\text { (Constant) } \\
\text { Organizational } \\
\text { Commitment (OC) } \\
\text { X3 }\end{array}$ & $\begin{array}{l}4.876- \\
.842\end{array}$ & $\begin{array}{l}.298 \\
.115\end{array}$ & -.592 & $\begin{array}{l}16.368 \\
-7.350\end{array}$ & $\begin{array}{l}.000 \\
.000\end{array}$ \\
\hline
\end{tabular}

a. Dependent Variable: Turnover Intention (TI) Y

Source: Data Processing 2018

Based on Table 15, a constant figure of 4,876 states that if there is organizational commitment, turnover intention is reduced by 4,876 . The regression coefficient for the $\mathrm{X} 2$ variable is -0.842 which means that it is negative, indicating that there is an opposite relationship between organizational commitment (X3) and turnover intention. For each increase in value between organizational commitment (X3), it causes a decrease in the level of turnover intention (Y) by 0.842 units. So the higher the organizational commitment, the lower the turnover intention, and vice versa, if the organizational commitment decreases, the employee turnover intention will also increase.

TABLE XVI. SuMmary WORKPlace Bullying (X4) MOdEL TO TURNOVER INTENTION (Y)

\begin{tabular}{|l|c|c|c|c|}
\hline Model & R & $\begin{array}{c}\text { R } \\
\text { Square }\end{array}$ & $\begin{array}{c}\text { Adjusted R } \\
\text { Square }\end{array}$ & $\begin{array}{c}\text { Std. error of the } \\
\text { Estimate }\end{array}$ \\
\hline 1 & $.433^{\text {a }}$ & .187 & .179 & .61069 \\
\hline \multicolumn{5}{|r}{ a. Predictors: (Constant), Workplace Bullying (WB) X4. }
\end{tabular}


Based on Table 16, to answer the problem "is there a relationship between workplace bullying (X4) and turnover intention (Y)", which is 0.433 (See R in the Model Summary table). The relationship between the independent variable and the dependent variable has a strong enough relationship (in the range $0.40-0.599)$. To answer the problem "whether the frequency of workplace bullying affects turnover intention". In this case using $\mathrm{R}$ Square or also called the coefficient of determination (KD). The coefficient of determination is 0.187 or equal to $18.7 \%$. This means that the influence of workplace bullying on turnover intention is $18.7 \%$ and the remaining $81.3 \%(100 \%-18.7 \%)$ is influenced by other variables not explained in this study, one of which is sexual harassment at work, work conflict.

TABLE XVII. ANOVA WORKPLACE BULLYING (X4) TO TURNOVER INTENTION (Y)

\begin{tabular}{|cl|l|l|l|l|c|}
\hline \multicolumn{10}{|c|}{ ANOVA $^{\mathbf{b}}$} & Sig. \\
& Model & $\begin{array}{c}\text { Sum of } \\
\text { Squares }\end{array}$ & \multicolumn{1}{|c|}{ df } & $\begin{array}{c}\text { Mean } \\
\text { Square }\end{array}$ & F & Sig. \\
\hline 1 & Regression & 8.591 & 1 & 8.591 & 23.037 & $.000^{\mathrm{a}}$ \\
& Residual & 37.294 & 100 & .373 & & \\
& Total & 45.885 & 101 & & & \\
\hline
\end{tabular}

a. Predictors: (Constant), Workplace Bullying (WB) X4. b. Dependent Variable: Turnover Intention (TI) Y Source: Data Processing 2018.

Based on Table 17, has a probability value of Sig. $=0.000$ $<0.05$, then Ho is rejected and $\mathrm{Ha}$ is accepted. It means that the regression coefficient is significant. The conclusion is that workplace bullying has a significant effect on turnover intention.

TABLE XVIII. COEFFICIENTS WORKPLACE BULLYING (X4) TO TURNOVER INTENTION (Y)

\begin{tabular}{|c|c|c|c|c|c|c|}
\hline \multicolumn{7}{|c|}{ Coefficients $^{a}$} \\
\hline \multirow{2}{*}{\multicolumn{2}{|c|}{ Model }} & \multicolumn{2}{|c|}{$\begin{array}{c}\text { Unstandardized } \\
\text { Coefficients }\end{array}$} & \multirow{2}{*}{$\begin{array}{c}\begin{array}{c}\text { Standardized } \\
\text { Coefficients }\end{array} \\
\text { Beta }\end{array}$} & \multirow[t]{2}{*}{$\mathbf{t}$} & \multirow[t]{2}{*}{ Sig. } \\
\hline & & B & $\begin{array}{c}\text { Std. } \\
\text { Error }\end{array}$ & & & \\
\hline & $\begin{array}{l}\text { (Constant) } \\
\text { Workplace } \\
\text { Bullying (WB) X4 }\end{array}$ & $\begin{array}{l}1.865 \\
.540\end{array}$ & $\begin{array}{l}.189 \\
.113\end{array}$ & .433 & $\begin{array}{l}9.886 \\
4.800\end{array}$ & $\begin{array}{l}.000 \\
.000\end{array}$ \\
\hline
\end{tabular}

a. Dependent Variable: Turnover Intention (TI) Y Source: Data Processing 2018

Based on Table 18, a constant figure of 1,865 states that if there is workplace bullying, turnover intention is reduced by 1,865 . The regression coefficient for the X4 variable of 0.540 means that it is positive, indicating a unidirectional relationship between workplace bullying (X4) and turnover intention (Y). For each increase in the value of workplace bullying (X4) it also causes an increase in turnover intention (Y) by 0.540 units. So the higher the workplace bullying, the higher the turnover intention, and vice versa, if workplace bullying decreases, the employee turnover intention will also decrease.
TABLE XIX. MULTIPLE REgRESSION SUMMARY MODEL

\begin{tabular}{|l|c|c|c|c|}
\hline Model & R & $\begin{array}{c}\text { R } \\
\text { Square }\end{array}$ & $\begin{array}{c}\text { Adjusted R } \\
\text { Square }\end{array}$ & $\begin{array}{c}\text { Std. error of the } \\
\text { Estimate }\end{array}$ \\
\hline 1 & $.746^{\mathrm{a}}$ & .557 & .539 & .45766 \\
\hline \multicolumn{5}{|c|}{ a. Predictors: (Constant), Workplace Bullying (WB) X4, Job Stress (JS) X1, Job } \\
Satisfaction (JSF) X2, Organizational Commitment (OC) X3. \\
\multicolumn{4}{c}{ Source: Data Processing 2018.}
\end{tabular}

Based on Table 19, to answer the problem whether there is a relationship between job stress variables, job satisfaction, organizational commitment, workplace bullying on turnover intention, which is 0.746 (See R in the Model Summary table). The relationship between the independent variable and the dependent variable has a strong relationship (in the range 0.60 $0.799)$. The coefficient of determination is 0.557 or equal to $55.7 \%$. This means that the magnitude of the influence of job stress, job satisfaction, organizational commitment, workplace bullying on turnover intention is $55.7 \%$ and the remaining $44.3 \%$ is the contribution of other variables not explained in this study, for example leadership style, motivational factors, performance appraisal or burnout in work.

TABLE XX. ANOVA Multiple REGRESSION

\begin{tabular}{|c|c|c|c|c|c|c|}
\hline \multicolumn{7}{|c|}{ ANOVA $^{b}$} \\
\hline & Model & $\begin{array}{c}\text { Sum of } \\
\text { Squares }\end{array}$ & df & $\begin{array}{c}\text { Mean } \\
\text { Square }\end{array}$ & $\mathbf{F}$ & Sig. \\
\hline 1 & $\begin{array}{l}\text { Regression } \\
\text { Residual } \\
\text { Total }\end{array}$ & $\begin{array}{l}25.569 \\
20.317 \\
45.885\end{array}$ & $\begin{array}{l}4 \\
97 \\
101\end{array}$ & $\begin{array}{l}6.392 \\
.209\end{array}$ & 30.519 & $.000^{\mathrm{a}}$ \\
\hline
\end{tabular}

Based on Table 20, it can be seen that the Sig column has a probability value. $\mathrm{Sig}=0.000<0.05$, then Ho is rejected and $\mathrm{Ha}$ is accepted, meaning that the regression coefficient is significant. The conclusion of job stress, job satisfaction, organizational commitment, workplace bullying has a significant effect on turnover intention.

The results of the $t$ test based on Statistical Product and Service Solutions processing are as follows:

TABLE XXI. PARTIAL HyPOTHESIS TESTING (T TEST)

\begin{tabular}{|l|l|l|l|l|l|l|}
\hline & T test & df & T table & \multicolumn{1}{c|}{ Sig } & \multicolumn{2}{c|}{ Conclusion } \\
\hline X1 & 2.414 & 97 & \pm 1.985 & 0 & Ho is rejected & Sig \\
\hline X2 & -2.899 & 97 & \pm 1.985 & 0.0018 & Ho is rejected & Sig \\
\hline X3 & -4.401 & 97 & \pm 1.985 & 0.005 & Ho is rejected & Sig \\
\hline$X 4$ & 5.080 & 97 & \pm 1.985 & 0 & Ho is rejected & Sig \\
\hline & & & & 0.001 & \multicolumn{4}{|c|}{ Source: Data Processing 2018} \\
\hline
\end{tabular}

Based on Table 21, (1) The variable X1 has a calculated t value greater than the $t$ table value. Because of $t$ value (2.414)> $\mathrm{t}$ table $( \pm 1.985)$, then Ho is rejected. Therefore it can be concluded that partially there is a significant effect of job stress 
(X1) on turnover intention (Y). (2) The variable X2 has a calculated $t$ value greater than the $t$ table value. Because of $t$ value $(-2.899)>t$ table $( \pm 1.985)$, then Ho is rejected. Therefore it can be concluded that partially there is a significant effect of job satisfaction (X2) on turnover intention (Y). (3) The variable $\mathrm{X} 3$ has a calculated $\mathrm{t}$ value greater than the $\mathrm{t}$ table value. Because of $t$ value $(-4.401)>t$ table $( \pm 1,985)$, then Ho is rejected. Therefore it can be concluded that partially there is a significant effect of organizational commitment (X3) on turnover intention (Y). (4) The variable $\mathrm{X} 4$ has a calculated $\mathrm{t}$ value greater than the $t$ table value. Because of $t$ value (5.080)> $t$ table $( \pm 1,985)$, then $\mathrm{Ho}$ is rejected. Therefore it can be concluded that partially there is a significant effect of workplace bullying (X4) on turnover intention (Y). To determine whether or not there is a significant effect of the independent variables on a dependent variable, the $\mathrm{F}$ test is used. The results of the F test based on SPSS processing are presented as follows:

TABLE XXII. OVERALL HYPOTHESIS TESTING (F TEST)

\begin{tabular}{|c|c|c|c|c|c|}
\hline$F$ value & Df & F table & Sig & \multicolumn{2}{|c|}{ Conclusion } \\
\hline 30.519 & $\begin{array}{l}\mathrm{df} 1=4 \\
\mathrm{df} 2=97\end{array}$ & 2.465 & 0,000 & $\begin{array}{l}\text { Ho } \\
\text { rejected }\end{array}$ & Sig \\
\hline
\end{tabular}

Source: Data Processing 2018

Based on Table 22, obtained the calculated $F$ value of 30.519. Because the calculated $F$ value (30.519)> $F$ table (2.465), then Ho is rejected. Thus it can be concluded that simultaneously there is a significant effect of job stress (X1), job satisfaction (X2), organizational commitment (X3) and workplace bullying (X4) on turnover intention (Y).

\section{CONCLUSION}

This study was conducted to analyse job stress variables, job satisfaction, organizational commitment, workplace bullying and turnover intention among employees of PT. Prudential. Job stress partially has a significant effect on turnover intention with $\mathrm{R}$ Square by $24.4 \%$. Job satisfaction partially has a significant effect on turnover intention with $\mathrm{R}$ Square by $19.1 \%$. Organizational commitment partially has a significant effect on turnover intention with $\mathrm{R}$ Square by $35.1 \%$. Workplace Bullying partially has a significant effect on turnover intention with R Square by $18.7 \%$. Job stress (X1), job satisfaction (X2), organizational commitment (X3), and workplace bullying (X4) simultaneously have a significant effect on turnover intention (Y) with R Square $55.7 \%$ for PT. Prudential employees. This can be interpreted in the research that partially has a low effect, and simultaneously has a greater influence than partially.

\section{REFERENCES}

[1] M.T. Manurung and I. Ratnawati, "Analisis Pengaruh Stres Kerja dan Kepuasaan Kerja terhadap Turnover Intention," Diponegoro Journal of Management, vol. 1, no. (2), 2012.
[2] R.D. Dhania "Pengaruh stres kerja, beban kerja terhadap kepuasaan kerja," Jurnal Psikologi Universitas Muria Kudus, vol. 1, no. (1), 2010.

[3] J. Ling, M.H. Yusof, and A.H. Rahman, "The Relationship between Organizational Commitment and Turnover Intention among Employee at a Manufacturing Company in Malaysia," International Information Institute, vol. 19, no. (8), pp. 3227-3231, 2016.

[4] S.E. Mette and A. Sökmen, "The Influence of Workplace Bullying on Employee's Job Performance, Job Satisfaction, and Turnover Intention in a Newly Established Privat Hospital," International Review of Management and Business Research, vol. 5, no. (1), 2016.

[5] A. Ahmad and S. Afgan, "The Relationship of Job Stress and Turnover Intention in Commercial Banks of Pakistan by Assesing the Mediating Role of Burnout," Journal of Business Strategies, vol. 10, no. (1), pp. 123, 2016.

[6] R. Andini, Analisis Pengaruh Kepuasan Gaji, Kepuasan Kerja, Komitmen Organisasional Terhadap Turnover Intention (Studi Kasus pada Rumah Sakit Roemani Muhammadiyah Semarang). Tesis. Semarang: Magister Manajemen Program Pasca Sarjana Universitas Diponegoro, 2006.

[7] Taurisa and I. Ratnawati, "Analisis Pengaruh Budaya Organisasi dan Kepuasan Kerja terhadap Komitmen Organisasional dalam Meningkatkan Kinerja Karyawan,” Jurnal Bisnis dan Ekonomi, vol. 19, no. (2), 2012

[8] P.S. Tarigan, Peran Bullying di Tempat Kerja Terhadap Intensi Turnover pada Karyawan. Skripsi. Universitas Sumatra Utara, 2015.

[9] L.A. Petrides and T.R. Nodine, Knowledge Management in Education. Institute for The Study of Knowledge Management in Education. 1 Mirada Road. Half Moon Bay CA 94019, 2003.

[10] Christin, "Peran Budaya Organisasi Dalam Mendukung Keberhasilan Implementasi Knowledge Management Systems," BINA EKONOMI, vol. 10, no. 1, pp. 1-120, 2006.

[11] A.E. Khan, M. Aqeel, and A.M. Riaz, "Impact of Job Stress on Job Attitudes and Life Satisfaction in College Lectures," International Journal of Information and Education Technology, vol. 4, no. (3), 2014

[12] J. Greenberg and R.A. Baron, Behavior in Organizations, 8th edition. Prentice Hall International edition, 2004

[13] S.P. Robbins and T.A. Judge, Organizational Behavior. Pearson Prentice Hall, 2011.

[14] A.M. Mosadeghrad, E. Ferlie, and D. Rosenberg, "A Study of Relationship between Job Stress, Quality of Working Life and Turnover Intention among Hospital Employees," Health Services Management Research, vol. 24, pp. 170-181, 2011.

[15] A. Rai and U. Agarwal, "Workplace Bullying: A Review and Future," South Asian Journal of Management, vol. 23, no. (3), 2016

[16] B.M Rousseau, A.K. Eddleston, C.P. Patel, and W.F. Kellermanns, "Organizational Resources and Demand Influence on Workplace Bullying," Journal Managerial Issues, vol. 26, no. (3), pp. 286-313, 2014.

[17] S. Noor and N. Maad, "Examining the Relationship between Work Life Conflict, Stress and Turnover Intentions among Marketing Executives in Pakistan," International Journal of Business and Management, vol. 3, no. (11), 2008.

[18] M. Golparvar, F. Abdoli, Z. Adibi, D. Mehryar, M. Taleb, and M. Mahabadi, "Moderating Impact of Job Recources on the Relationship between Job Stress with Turnover Intention and Creativity," American Journal of Economics, Finance dan Management, vol. 1, no. (5), pp. 388-398, 2015.

[19] Y. Zhang and X. Feng, "The Relationship between Job Satisfaction, Burn out, and Turnover Intention among Physicions FromUrban State Owned Medical Institutions in Hubei, China: A Cross - Sectional Study," BMC Health Services Research, vol. 11, p. 235, 2011.

[20] D. Sunyoto, Sumber Daya Manusia. Yogyakarta: PT. Buku Seru, 2013. 